\title{
Morphological variability, host range and distribution of ticks of the Rbipicephalus sanguineus complex in Israël
}

\author{
by Ilan PAPERNA (1) and Miriam GILADI \\ At the Kimron Veterinary Institute Beit-Dagan, Israel
}

Summary

Three distinct populations may be observed in ticks of the Rhipicephalus sanguineus complex in Israel :

Ticks with the genital aperture of the females characteristic of $R$. secundus FeldmanMuhsam, 1952 and light scutal punctation (socalled type x), distributed in the Mediterranean zone on cattle, sheep, goats and small wild mammals.

$R$. sanguineus s. str., females with the characteristic genital aperture of this species and with light scutal punctation, distributed in the Mediterranean zone on dogs.

$R$. sanguineus s.str., females with the typical genital aperture of this species and with heavy scutal punctation; confined to the arid south, found on dogs, sheep goats, camels and small wild mammals.

The male punctation pattern is not directly linked with the grouping in females, therefore their identity when collected in the field cannot be directly determined from morphological characteristics.

The $300 \mathrm{~mm}$ isohyete apparently forms the distribution border between the heavily punctated and lightly punctated types. However $R$. secundus are occationally carried south on the hosts, sheep and goats, when these are taken for sale to a market town: situated in the arid zone.

Intermediate types occasionally found in this area suggest possible crossing in nature between $R$. secundus and the punctated type of $R$. sanguineus.

(1) Present address: The Heinz Steinitz Marine Biology Laboratory, Etat, Israël. 


\section{Résumé}

Variabilité morphologique, affinités pour l'hôte et distribution géographique des tiques du complexe Rhipicephalus sanguineus en Israël.

Trois populations distinctes peuvent être observées dans ce complexe:

1) Les tiques ayant un orifice génital femelle caractéristique de $R$. secundus FeldmanMuhsam, 1952, et un scutum orné de ponctuations fines (type x). Elles sont présentes dans la région méditerranéenne chez les bovins, moutons, chèvres et petits mammifères sauvages.

2) Les $R$. sanguineus s. str. dont les femelles ont l'orifice génital caractéristique de l'espèce et dont le scutum portent des ponctuations fines du type $\mathrm{x}$. On les observe chez les chiens dans la région méditerranéenne.

3) Les $R$. sanguineus s. str. dont les femelles ont un orifice génital caractéristique de l'espèce et dont le scutum porte des ponctuations épaisses. Ces tiques sont confinées dans le sud aride chez les chiens, les moutons, les chèvres, les chameaux et les petits mammifères sauvages.

La disposition des ponctuations scutales chez le mâle n'est pas liée directement à celle des femelles; aussi leur identité ne peut-elle être immédiatement déterminée par les caractères morphologiques lorsqu'on les récolte sur le terrain.

L'isohyète de $300 \mathrm{~mm}$ constitue apparamment la frontière entre les espèces à ponctuations fines et celles à ponctuations épaisses. Cependant, les $R$. secundus sont parfois entraînés dans le sud par leurs hôtes, moutons et chèvres, lorsque ceux-ci sont transférés en zone aride pour être vendus au marché d'une agglomération.

On trouve parfois dans cette zone des espèces intermédiaires, ce qui suggère l'éventualité d'un croisement naturel entre $R$. secundus et $R$. sanguineus.

\section{Introduction}

Ticks included in the «Rhipicephalua sanguineus complex» are represented in Israel by $R$. sanguineus s. str. and $R$. secundus, separated from the former by FeldmanMuhsam (1952) on the basis of diferences in the shape of the female genital aperture. Males of these two species cannot be separated on the basis of morphological characters. Feldman-Muhsam also noted differences which exist in the host preferences of these two species, namely that adult $R$. sanguineus feeds predominantly on dogs, while $R$. secundus is predominantly a parasite of cattle, sheep and goats (Feldman-Muhsam, 1952-1967, Feldman-Muhsam and Saturen, 1961). More recently, however, FeldmanMuhsam (1967) suggested possible synonymy between $R$. secundus and $R$. turanicus Pomerantzev, Metkashvilli and Lototzki, 1940.

Hybridisation experiments between female $R$. sanguineus and male $R$. secundus carried out recently by the late Dr. Cwillich (Cwillich and Hadani, undated internal report) and by the author (Paperna, unpublished) yielded normal offspring which were bred to $\mathrm{F}_{3}$; back crossing with $R$. secundus also yielded normal offspring. However, the 
reciprocal crossing of $R$. sanguineus and $R$. secundus failed. Pervomayski (1950) also reports complete success in crossing $R$. sanguineus and $R$. turanicus, but no further details on these experiments were given.

Checking ticks collected from different hosts from the different climatic zones of the country has shown the existence of distinct variations in the pattern of scutal punctation of the female tick.

Similar differences were observed in the punctation of the scute of males, but they were independant of those found in females. The types of punctation were only partly associated with the $R$. sanguineus - R. secundus division.

\section{Results}

Types of punctation of the female scutum :

Type P ; scutum densely and distinctly covered with coarse punctation (fig. 6-9).

Type $\mathrm{p}$; scutum not punctated of with only few coarse punctation (fig. 13).

Intermediate types; scutum only partly punctated (fig. 4-5).

Type $\mathrm{x}$; scutum lacks coarse punctation but is covered completely with very fine hardly visible punctation (fig. 1-3, 10-12).

\section{Types of punctation on males :}

Type $\mathrm{P}$; scutum has both sparse coarse punctation and dense fine punctation (fig. 17, 18, 20).

Type $\mathrm{p}$; dense punctation is absent, only coarse punctation exists (fig. 16, 19).

Correlation between the pattern of punctation in female ticks and the $R$. secundus - $R$. sanguineus division according to the genital pore structure :

Ticks typed as $R$. secundus according to the structure of their genital pore normally have type $\mathrm{x}$ scutal punctations, or lack punctation completely. Only rarely such ticks showed coarse punctation, but it is possible that such a pattern is merely a more pronounced type of $\mathrm{x}$-punctation.

Ticks typed as $R$. sanguineus may have either the coarse type $\mathrm{P}$ punctation or the fine type $\mathrm{x}$ punctation. In populations showing type $\mathrm{P}$ punctation type $\mathrm{p}$ occurs too, but care must be taken to avoid confusing type $\mathrm{p}$ with type $\mathrm{x}$.

Geographical distribution and host preference of female ticks of the different sub-groups.

1. $R$. secundus type $\mathrm{x}$ (and type $\mathrm{p}$ ): Sheep, goats, cattle, hedgehog (Erinaceus europeus) and hare (Lepus syriacus) in the north and central parts of Israel ; on sheep, goats and cattle in the Golan heights. 

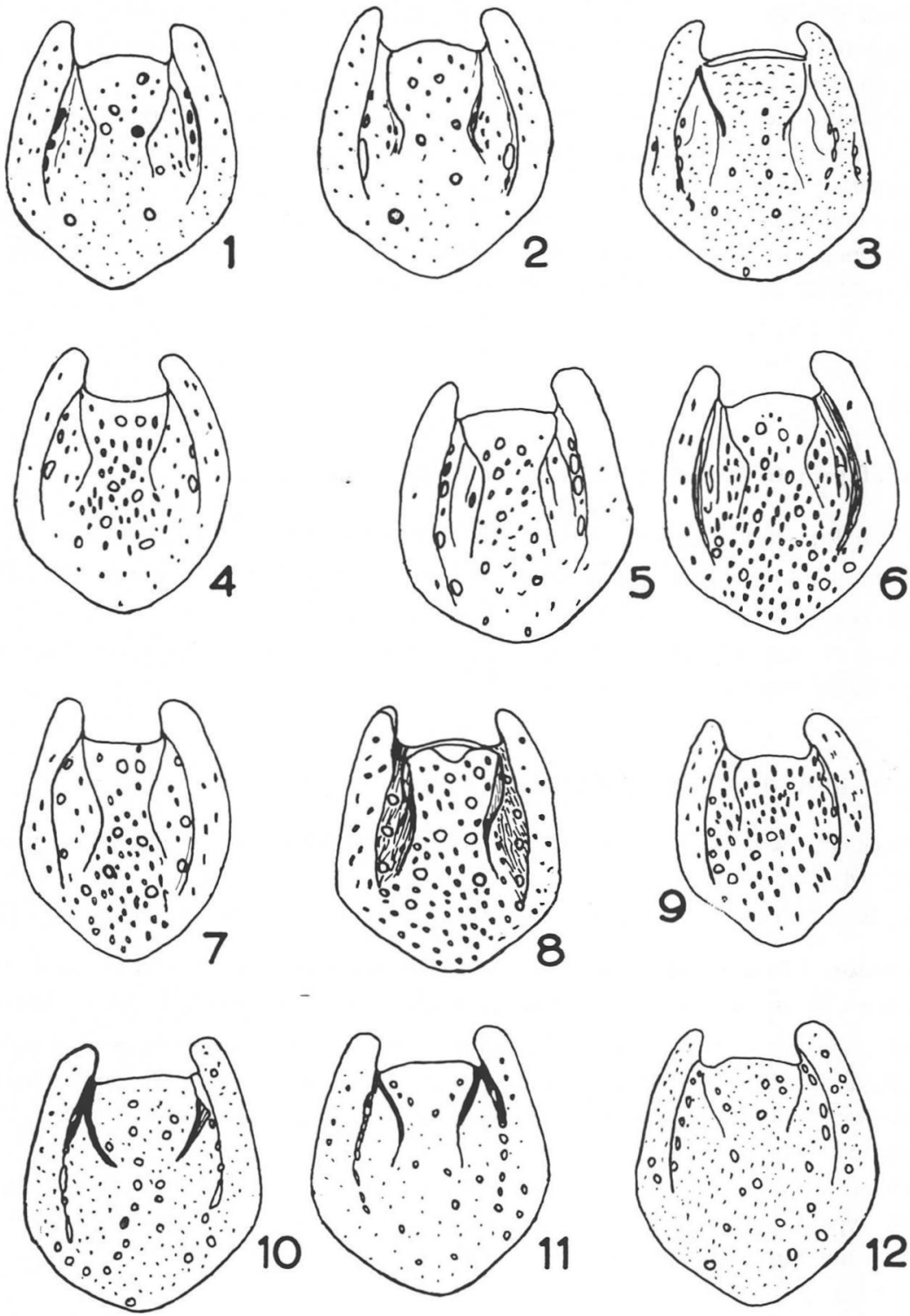

FIG. 1 à 12

1-3. - R. sanguineus o type-x from dogs from Kfar Tabor (the north) $(1,2)$ and Nablus (the center), - 4. - $R$. sanguineus, o intermediate type from a goat from Beer Sheva (south), -5 . $-R$. sanguineus, $q$ intermediate type, close to type $\mathrm{p}$, from a dog, Beer Sheva (south), -6 . $-R$. sanguineus, $ᄋ$ type-P, from same host as fig. 5 specimen, - 7-9. $-R$. sanguineus, o type $\mathrm{P}$, from sheep, Arad (the desert) zone in the south, - 10-12. - R. secundus, o type-x, from cow, from Neve-Eitan (north) $(10,12)$, and sheep from Lod area (center) (11) 
In the arid south, $R$. secundus is replaced by the other species but may still be found on sheep and goats brought for sale from northern areas to the Beduin market in Beer-Sheva. It appears that this tick is normally restricted to the more humid Mediterranean climatic zone of the country, being apparently distributed north of the $300 \mathrm{~mm}$ isohyete (2); but it may be carried on its host further south.

2. $R$. sanguineus, type $\mathrm{x}$ and type $\mathrm{p}$ : on dogs, throughout the central and northern part of the country. Found also in the Golan heights.

Like the previous type is apparently restricted to the Mediterranean humid zone north of the $300 \mathrm{~mm}$ isohyete.
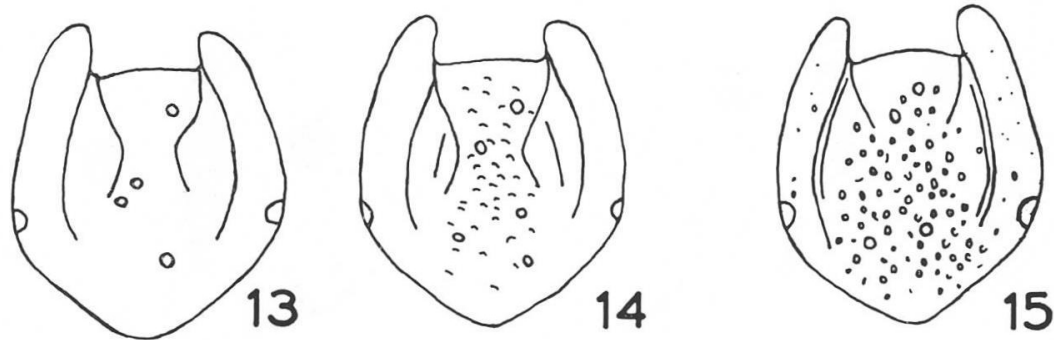

FIG. 13-15. - R. sanguineus $q$ collected from one long-eared Hedgehog from Gilat (south). All three types are represented type-P (15) type-p (13) and intermediate type with slight punctation (14).

3. R. sanguineus, type P: The hosts are sheep, goats and camels and also dogs. Was found also on the long-eared hedgehog (Hemiechinus auritus) and the desert fox (Vulpes vulpes rupelli). The tick is found south of the $200-300 \mathrm{~mm}$ isohyete in the desert zone in the south of Israel and Sinai. Among the punctated ticks, on the same host, may also be found specimens with the scutum only partially punctated and also some specimens with non-punctated scutum (type p). A few punctated specimens were also found in the north and in the Golan heights.

$R$. sanguineus earlier recorded by Feldman-Muhsam (1960) from the vicinity of Santa Katherina monastery in Sinai ; on goats dogs and cats and also on fox, hare and the desert hedgehog (Paraechinus dorsalis), is apparently of the same type P.

It is not certain whether the ticks found on dogs and those found on goats and sheep comprise one population or are maintained as two distinct populations ; in any case their morphology seems to be identical.

4. Intermediate types: In the vicinity of Beer Sheva and in the southern part of the coastal plain, in the intermediate zone between the Mediterranean and the arid zones, both $R$. sanguineus and $R$. secundus may be obtained from sheep and goats.

(2) In the Jordan valley the southern limit for the tick is apparently the $200 \mathrm{~mm}$ isohyete. Sheep and goats checked in Jerico and further north were not infected with these ticks. 

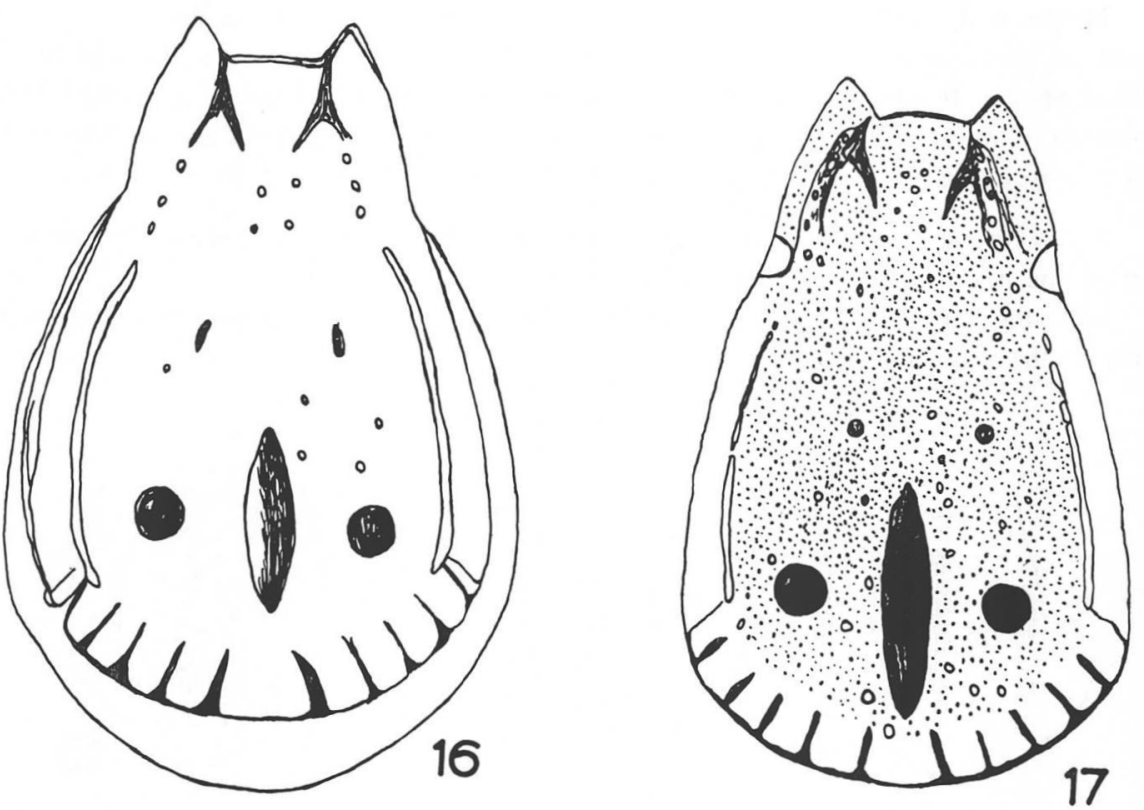

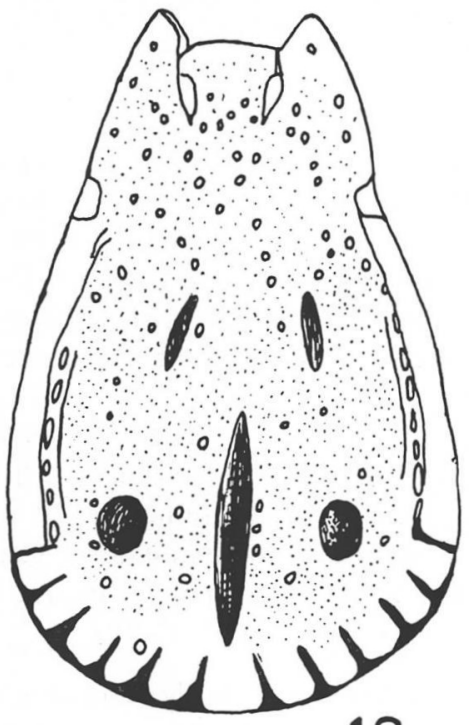

18

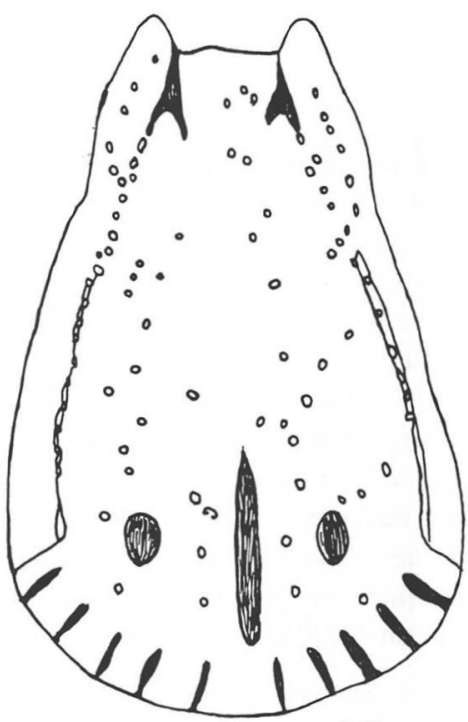

19

FIG. 16 à 19

16. - R. sanguineus, male, non punctated from sheep, Beer Sheva (south), -17 . $-R$. sanguineus, male punctated, from sheep Beer Sheva (scuth), - 18. - R. secundus, $\hat{\alpha}$ punctated, from a cow, Neve Eitan (north), - 19. - R. secundus, ô non punctated, from a sheep, Tirosh (center) 
Among the collected ticks we could find females with genital pore structure intermediate between «secundus» and «sanguineus» types. Punctation in such females is of type $\mathbf{P}$, and more rarely type $\mathrm{p}$, but none was of type $\mathrm{x}$.

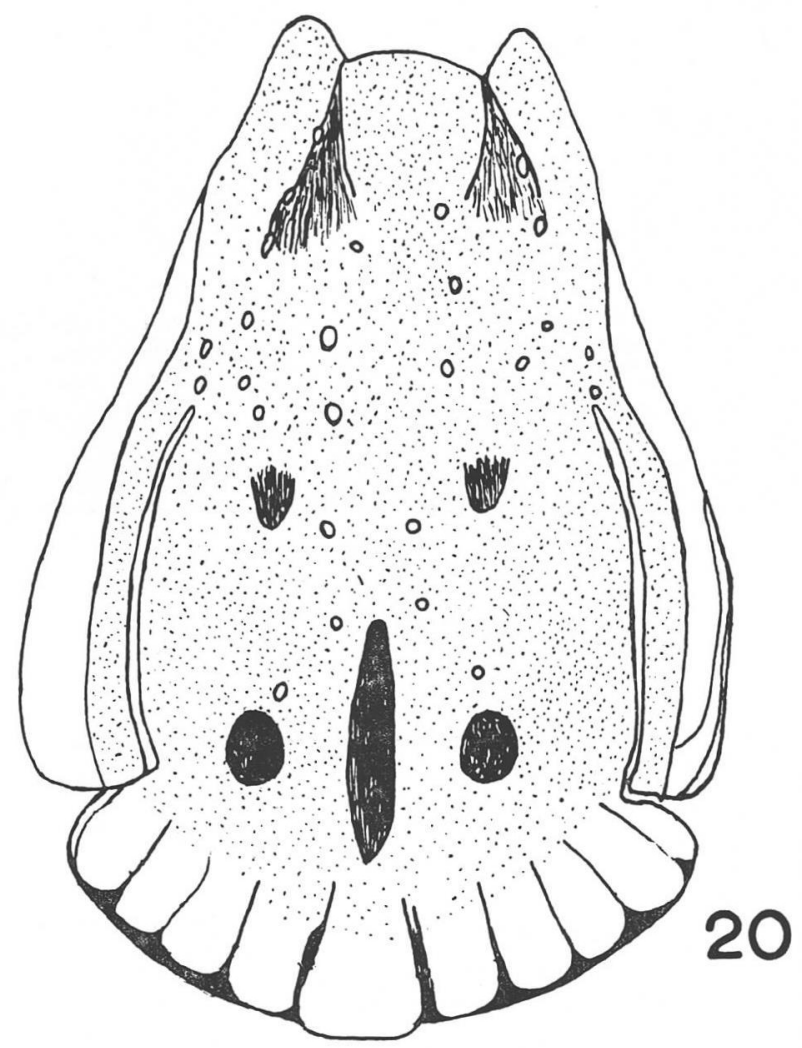

Fig. 20. $-R$. sanguineus, punctated, $\delta^{2}$ from a dog, Nablus (center).

Among the females with «secundus» type genital pores in these populations, type $\mathrm{x}$ scutal punctation was dominant, with only a few showing types $\mathrm{P}$ and $\mathrm{p}$. Among «sanguineus» collected from this area type $\mathrm{x}$ was extremely rare.

\section{Breeding in the laboratory :}

Examination of offspring reared from single females of the different morphological types (Table I) has shown that all offspring possesed the same type of genital aperture as their mothers. 


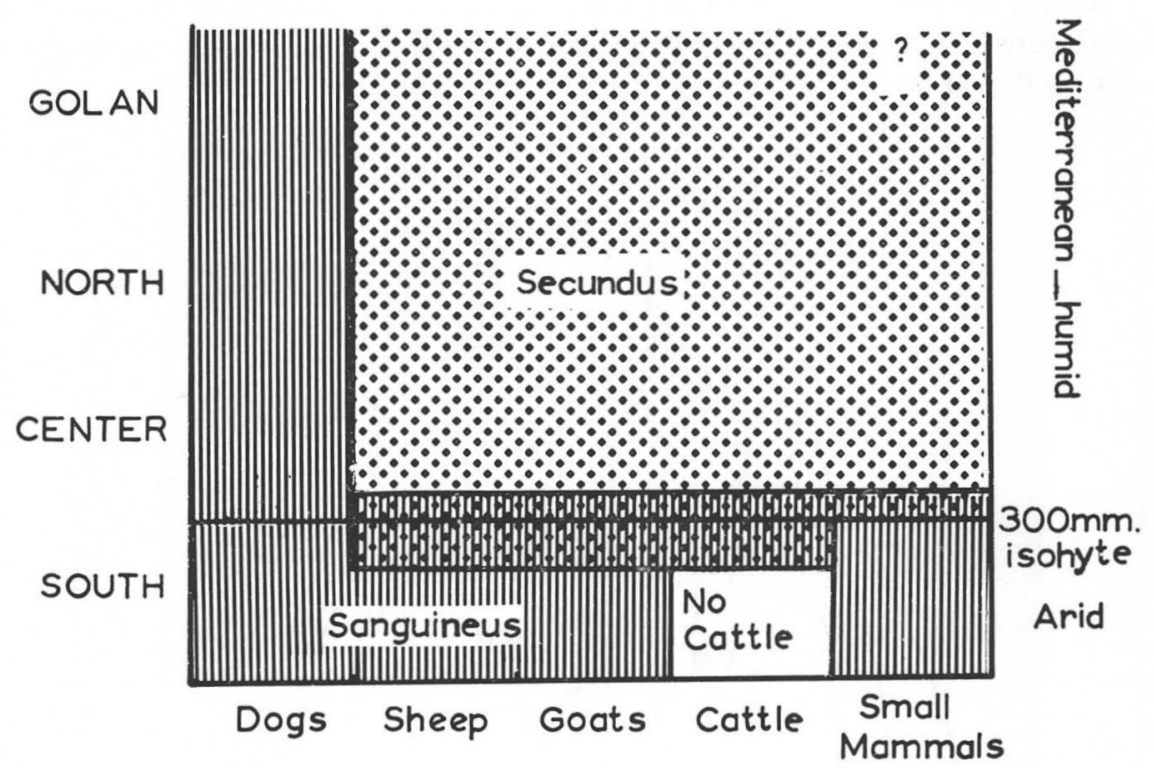

FIG. 21. - Distribution and host range of $R$. sanguineus and $R$. secundus in Israel.

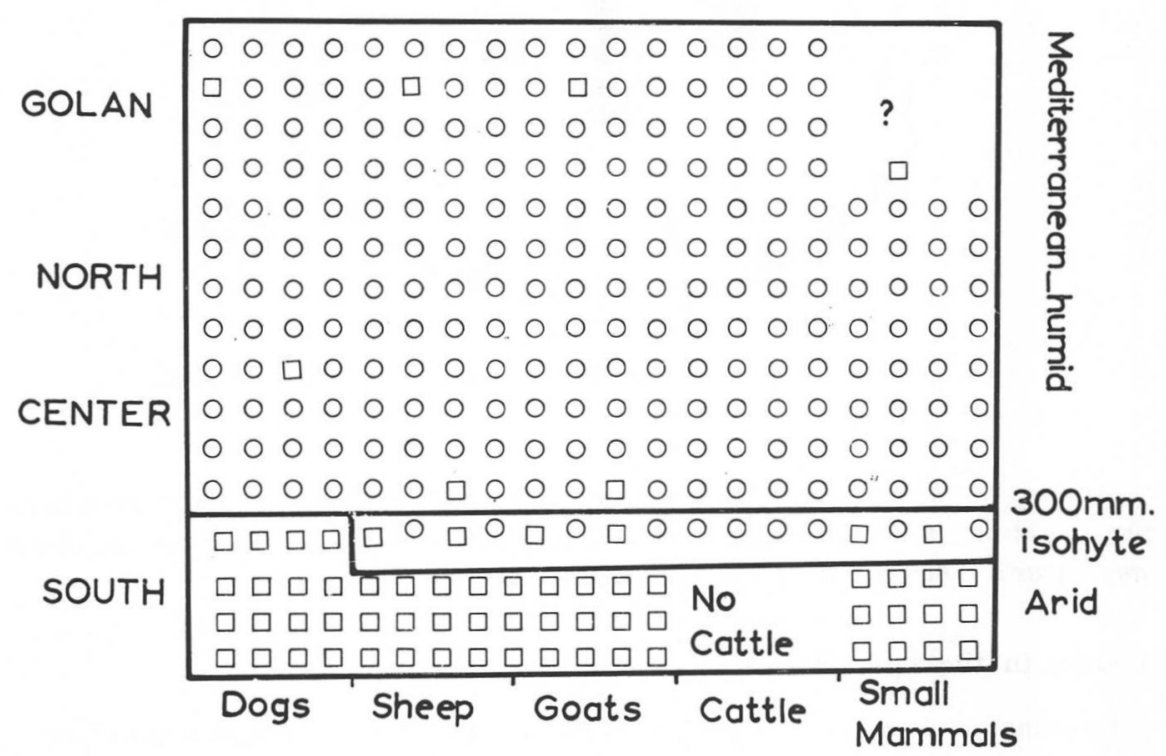

FIG. 22. - Distribution of the type-P ant type-x punctation patterns in the «R. sanguineus complex» in Israel. Squares symbols type-P, circles, type-x. 
In the progeny of a type $\mathrm{p}$ mother we could find among the punctated forms also partly punctated and non-punctated, (totalling up to $8 \%$ of the progeny). All the progeny of type $\mathrm{x}$ mothers either have the fine type $\mathrm{x}$ punctation or lack any punctation, and thus were classified as type p. Apparently, these however, non-

TABLE I. - Results of laboratory rearing of single female progeny.

\begin{tabular}{|c|c|c|c|c|c|c|c|c|c|}
\hline \multicolumn{4}{|c|}{ Parent female } & \multicolumn{3}{|c|}{ Offsprings $\rightarrow$ females } & \multicolumn{3}{|c|}{ Males } \\
\hline Punct. & $\begin{array}{l}\text { Gen. App. } \\
\text { type }\end{array}$ & Host & Locality & P-type & p-type & $\begin{array}{c}x- \\
\text { ty- } \\
\text { pe }\end{array}$ & $\mathrm{P}$ & non- & $\begin{array}{l}\mathrm{m} / \mathrm{f} \\
\text { ratio }\end{array}$ \\
\hline$P$ & sanguineus & sheep & desert (1) & 115 & 10 & 0 & 111 & 7 & 0,88 \\
\hline $\mathrm{P}$ & $»$ & $\gg$ & desert (2) & ++++ & 2 & 0 & & & \\
\hline $\mathrm{P}$ & $»$ & $》$ & Beer- & 9 & 8 & 0 & & & \\
\hline$P$ & & & Sheva & & & & & & \\
\hline$P$ & $\gg$ & $\operatorname{dog}$ & $\gg$ & 100 & & & & & \\
\hline $\mathrm{P}$ & $\gg$ & $\gg$ & $\gg$ & 15 & & & 21 & & 0,71 \\
\hline $\mathrm{P}$ & » & $»$ & $»$ & 23 & & & ++ & & \\
\hline $\mathrm{p}$ & $\underset{\gg}{\text { secundus }}$ & $\begin{array}{l}\text { goat } \\
\text { sheep }\end{array}$ & » & & ++++ & 21 & & 13 & 0,62 \\
\hline $\mathrm{x}$ & $\gg$ & cow & north (3) & & 11 & 8 & 10 & & 0,53 \\
\hline $\mathrm{x}$ & $\gg$ & cow & $\gg$ & & 52 & 11 & 73 & & 1,16 \\
\hline $\mathrm{x}$ & $\gg$ & hedgehog & $\gg(4)$ & & 7 & 148 & & 158 & 1,03 \\
\hline $\mathrm{p}(\mathrm{x}$ ?) & sanguineus & dog & north (5) & & 21 & 183 & & 213 & 1,04 \\
\hline
\end{tabular}

punctated forms which derive from type $\mathrm{x}$ are different from the non-punctated forms found among the progeny of P-mothers.

\section{Subgrouping of males :}

Both «punctated» and "non-punctated» types occured in the progeny of $R$. sanguineus and $R$. secundus, thus the punctation character is not linked with the «sanguineus-secundus » division as in females. (Table II).

Punctated males were dominant in the progeny of type $\mathrm{P}$ females from the arid south and also in the progeny of some type $\mathrm{x}$ females from the Mediterranean zone. Non-punctated males were prevalent in progeny from type $\mathrm{x}$ females both $R$. secundus and $R$. sanguineus; in the progeny of type $\mathrm{P}$ females this type was rare.

Males reared in the laboratory maintained the same punctation pattern as males recovered from the same host as their mother. 
TABLE II. - Punctation pattern in males in relation to host, locality and punctation pattern in the females.

\begin{tabular}{|c|c|c|c|c|}
\hline \multirow{2}{*}{ Host } & \multirow{2}{*}{ Locality } & \multirow{2}{*}{ Female punct. } & \multicolumn{2}{|c|}{ male punctation } \\
\hline & & & Punct. & non punct. \\
\hline Sheep & south & P-type & ++++ & rare \\
\hline Goast & south & P-type & ++++ & \\
\hline Dogs & south & P-type & +++ & + \\
\hline Cattle & north & $x$-type & ++ & ++ \\
\hline & Golan & $\mathrm{x}$-type & +++ & \\
\hline Sheep & centre-north & $\mathrm{x}$-type & & ++++ \\
\hline Goats & centre-north & $x$-type & & ++++ \\
\hline & Golan & $x$-type & ++ & ++ \\
\hline Hedgehog & north & $x$-type & & ++++ \\
\hline Dog & north & $\mathrm{x}$-type & & ++++ \\
\hline
\end{tabular}

\section{Discussion}

Hoogstraal (1956) records variations similar to those described above in the scutal punctation of $R$. sanguineus in the Sudan. Apparently these variants are not related to those described in this paper. Our punctated variant is confined to the arid zones, whereas the more punctated variant in the Sudan is found in the humid south while the lightly punctated one is typical of the arid north.

Hoogstraal could not find ticks with a «secundus» type genital aperture in the Sudan and Egypt.

Heavily punctated $R$. sanguineus resemble $R$. sulcatus, a common tick of the Ethiopian zone, once considered to be a subspecies of $R$. sanguineus. Hoogstraal (1956) and Feldman-Muhsam (1967) consider R. sulcatus as valid species and were able to distinguish it clearly from punctated $R$. sanguineus. According to FeldmanMuhsam (personal communication) our punctated population is also clearly distinct from the type known as $R$. sanguineus punctatissimus Gerstracker, 1873.

It appears that the punctation pattern of the males is not directly linked with that of the females. In females it is also not distinctly linked with the «sanguineussecundus » division, since a common pattern of punctation (type $\mathrm{x}$ ) characterizes both $R$. sanguineus and $R$. secundus in the Mediterranean zone of Israel (north of the $300 \mathrm{~mm}$ isohyete). Heavily punctated scuta are found predominantly in $R$. sanguineus of the arid south (south of the $300 \mathrm{~mm}$ isohyete). In this population males also are normally punctated.

The punctation pattern is genetically controlled and is transferred within each population from females to their female offspring. 
When $R$. secundus is crossed with $R$. sanguineus, the $F_{1}$ females maintain the punctation pattern of the female parent, while the genital aperture is of an intermediate type.

In $\mathrm{F}_{2}$ both the punctation pattern and the genital aperture character segregate, but the punctation pattern is not linked with the «sanguineus»- «secundus 》 type genital aperture out tended to be punctated, while those showing intermediate type (closer to «sanguineus» type) tended to be non-punctated (Paperna, unpublished).

\section{AKNOWLEDGEMENT :}

I wish to thank Mr I. J. Linn from the Zoology Department, Makerere University Kampala for his valuable critisism of the manuscript.

\section{References}

Feldman-Muhsam (B.), 1952. - On the identity of Rhipicephalus sanguineus LAT. Bull. Res. Coun. Israel 2 (2), 187-194.

-, 1967. - The Rhipicephalus sanguineus complex $W H O / V B C / 68.57$, paper 4 (2), 133120.

—, and SATUREN (I. M.), 1961. - Notes on the ecology of Ixodid ticks of domestic stock in Israel. Bull. Res. Counc. Israel $10 \mathrm{~B}$ : 53-61.

Hoogstraal (H.), 1956. - Ticks of the Sudan. Dep. of the Navy, Bureau of Medicine and Surgery, $1101 \mathrm{p}$. 